\title{
Undernutrition and fertility of male rats
}

\section{Ghafoorunissa}

\author{
National Institute of Nutrition, Indian Council of Medical Research, Jamai Osmania (PO), \\ Hyderabad - 500 007, A.P., India
}

\begin{abstract}
Summary. Food intake in rats was restricted so that the energy intake was 80 and $60 \%$ that of animals fed ad libitum. Although body weight gain was depressed, none of the other measurements taken (epididymal sperm count, fructolytic activity of spermatozoa, relative weights of the reproductive organs, concentration of fructose in coagulating glands and fertility in relation to females impregnated, conceiving and litter size) was affected.
\end{abstract}

\section{Introduction}

Despite the belief that malnutrition imposes severe constraints on reproduction and fertility, high rates of population growth are observed in areas where large segments of the human population are undernourished. The available evidence on inter-relationships between fertility and nutrition is based mostly on studies of the female (Nelson, 1959; Gopalan, 1962; Callard \& Leathem, 1970; Widdowson \& Cowen, 1972; Gopalan \& Naidu, 1974). Data on the male are scanty. Chronic malnutrition in adult men leads to a decrease in urinary gonadotrophins and is associated with gonadal atrophy (Zubiran \& Gomez-Mont, 1953). The most common effect of underfeeding or dietary imbalance appears to be suppression of the endocrine activity of the testes and, consequently, growth retardation and diminished secretory activity of the accessory organs of reproduction (Mann, 1964, 1974). Food restriction of male calves delays sexual maturity and reduces androgenic activity (Mann, 1964). All these investigations on the nutritional-gonadal relationship were conducted on animals with severe nutritritional deficiencies and no attempt has been made to correlate the observed changes with the fertility of the animals. The present studies are an investigation of the effect of moderate undernutrition on the fertility of male rats.

\section{Materials and Methods}

The 90 males used were $25-28$ days old weanling albino Wistar rats with a mean weight of 48.7 $\pm 1.35 \mathrm{~g}$, from the animal colony of the National Institute of Nutrition, Hyderabad. Three groups were formed giving equal representation to litter-mates and body weight. The basic diet was composed exclusively of foods of vegetable origin and provided $20 \%$ protein and contained extra vitamins and minerals. The composition of the diet was similar to that described by Ghafoorunissa (1976). The rats in Group I were allowed to feed ad libitum and the food intake was recorded daily. The food given to animals in Groups II and III was gradually reduced over a 6-day period to $80 \%$ and $60 \%$ respectively of the diet consumed by the corresponding control rats in Group I. The animals were maintained on these diets for 12 weeks and their reproductive performance was then studied. 
The 420 female rats were also weanlings and were maintained on the basic diet provided ad libitum for 11 weeks. They were then changed to a diet that also provided $20 \%$ protein but the protein was derived partly from casein and skimmed milk. After feeding this diet for 1 week, the body weights of the females were $115-185 \mathrm{~g}$. Vaginal smears were taken from all the females and those in pro-oestrus or late dioestrus were selected for mating. They were divided into 3 groups so that body weights and stage of the oestrous cycle were similar. Each female was housed with 1 experimental male in the evening and the presence of spermatozoa in the vaginal smear was checked the next morning. When the smear was negative, the animals were left together again overnight. A positive smear was taken as evidence of mating (Day 1). The females were then separated and were fed the $20 \%$ protein diet containing casein and skimmed milk. This pattern of mating was repeated for each male rat with 2 more females at intervals of 2 days between consecutive matings. At 12 days after mating the females were killed under ether anaesthesia, the uterine horns were opened and the number of live and dead embryos were counted. The mutagenic index was calculated as the no. of dead embryos $\times 100 /$ total no. of embryos.

The male rats were killed 2 days after the last mating. The reproductive organs were removed and all except the epididymis were freeze dried, weighed and stored at $-20^{\circ} \mathrm{C}$ until analysis. Spermatozoa were obtained from the cauda epididymidis by the method of Morita \& Chang (1970). An aliquot was appropriately diluted with Krebs-Ringer phosphate buffer, pH 7.4, and a sperm count was made using a haemocytometer. The remaining spermatozoa were washed and the metabolism of $\left[\mathrm{U}^{14} \mathrm{C}\right]$ fructose was studied by a modification (Ghafoorunissa, 1976) of the method of Morita \& Chang (1970). The lactic acid formed from the $\left[{ }^{14} \mathrm{C}\right]$ fructose was estimated radiochemically by the method of Hoskins \& Patterson (1968). Fructose was estimated in the coagulating glands and seminal vesicles by a modification of Roe's method as described by Mann (1964).

\section{Results}

All the results are shown in Tables 1 and 2. Rats in Groups II and III failed to gain as much weight as did those in Group I and the weight difference was proportional to the extent of dietary restriction, being $79 \%$ of Group I values in Group II and $67 \%$ in Group III (Table 1). There were no significant effects on the fertility of the males.

Table 1. Effect of food restriction on body weights and reproductive performance of male rats (30/group)

\begin{tabular}{lccc}
\hline & $\begin{array}{c}\text { Group I } \\
\text { (ad libitum) }\end{array}$ & $\begin{array}{c}\text { Group II } \\
(80 \%)\end{array}$ & $\begin{array}{c}\text { Group III } \\
(60 \%)\end{array}$ \\
\hline Body weight (g) & & & \\
$\quad$ At 1st mating & $252 \pm 5.4$ & $205 \pm 5.2$ & $168 \pm 4.4$ \\
$\quad$ At 2nd mating & $259 \pm 5.0$ & $217 \pm 4.4$ & $182 \pm 3.6$ \\
$\quad$ At 3rd mating & $268 \pm 4.9$ & $224 \pm 4.6$ & $187 \pm 3.8$ \\
No. of females mated & $60 / 87$ & $50 / 87$ & $51 / 87$ \\
No. of males mating with 2 or 3 females & 22 & 18 & 18 \\
No. of embryos/pregnant female & $10.0 \pm 0.25$ & $9.8 \pm 0.25$ & $9.4 \pm 0.50$ \\
Mutagenic index & $5.1 \pm 1.15$ & $8.2 \pm 2.1$ & $6.7 \pm 1.52$ \\
\hline
\end{tabular}

Values are mean \pm s.e.m. for the no. of observations in parentheses.

* All females that mated became pregnant.

The mean weights of all the reproductive organs measured were significantly lower in Groups II and III than in the controls, but when expressed in terms of unit body weight mean values for testes and epididymides were significantly higher in Groups II and III (Table 2). There was little difference between the 3 groups for the other measurements recorded (Table 2). 
Table 2. Effect of food restriction on organ weight, sperm count and sperm metabolism

\begin{tabular}{|c|c|c|c|}
\hline & $\underset{(\text { ad libitum })}{\text { Group I }}$ & $\begin{array}{l}\text { Group II } \\
(80 \%)\end{array}$ & $\begin{array}{l}\text { Group III } \\
(60 \%)\end{array}$ \\
\hline Body weight (g) (29) & $276 \cdot 7 \pm 5 \cdot 35$ & $226 \cdot 0 \pm 3 \cdot 60^{a}$ & $184 \cdot 0 \pm 2.91^{\mathrm{sb}}$ \\
\hline \multicolumn{4}{|l|}{$\begin{array}{l}\text { Relative organ weight }(\mathrm{mg} / 100 \mathrm{~g} \\
\text { body weight) }\end{array}$} \\
\hline Testes (27) & $152.3 \pm 3.27$ & $180 \cdot 2 \pm 3.94^{\mathrm{a}}$ & $216 \cdot 0 \pm 3 \cdot 82^{\mathrm{ab}}$ \\
\hline Epididymides (28) & $340.0 \pm 7.7$ & $382.8 \pm 8.0^{\mathrm{a}}$ & $430 \cdot 3 \pm 6 \cdot 6^{\mathrm{ab}}$ \\
\hline Prostate (19) & $65 \cdot 1 \pm 3.54$ & $65 \cdot 2 \pm 4 \cdot 50$ & $57.8 \pm 2.70$ \\
\hline Seminal Vesicles (16) & $64.4 \pm 2.61$ & $69.7 \pm 2.95$ & $71.2 \pm 2.73$ \\
\hline Coagulating glands (28) & $13.2 \pm 0.73$ & $14.6 \pm 0.89$ & $14.5 \pm 1.23$ \\
\hline \multicolumn{4}{|l|}{ Sperm count $\times 10^{8}$} \\
\hline Total number & $1.07 \pm 0.071$ & $0.99 \pm 0.072$ & $\begin{array}{c}0.76 \pm 0.057^{\mathrm{cd}} \\
(30)\end{array}$ \\
\hline No./g epididymis & $1 \cdot 13 \pm 0.071$ & $1 \cdot 13 \pm 0.091$ & $\begin{array}{c}0.97 \pm 0.079 \\
(29)\end{array}$ \\
\hline \multicolumn{4}{|l|}{ Fructose (mg/g dry tissue) } \\
\hline Coagulating glands (28) & $3.5 \pm 0.25$ & $3.6 \pm 0.21$ & $3.4 \pm 0.16$ \\
\hline Seminal vesicles (15) & $0.42 \pm 0.051$ & $0.44 \pm 0.040$ & $0.43 \pm 0.051$ \\
\hline \multicolumn{4}{|l|}{ Fructose metabolism } \\
\hline$\mu \mathrm{g}$ fructose oxidized to & $3 \cdot 3 \pm 0.72$ & $3.2 \pm 0.62$ & $2.9 \pm 0.51$ \\
\hline${ }^{14} \mathrm{CO}_{2} / \mathrm{h} / 10^{8}$ cells & (24) & (23) & (26) \\
\hline$\mu \mathrm{g}$ lactate formed $/ \mathrm{h} / 10^{8}$ cells $(15)$ & $43.2 \pm 10.04$ & $44 \cdot 8 \pm 12.09$ & $41.4 \pm 11.01$ \\
\hline
\end{tabular}

Values are mean \pm s.e.m. for the no. of observations in parentheses.

Significantly different from Group I value, ${ }^{a} P<0.001,{ }^{\mathrm{c}} P<0.01$.

Significantly different from Group II value, ${ }^{b} P<0.001,{ }^{d} P<0.02$.

\section{Discussion}

The male reproductive system is dependent on adequate nutrition for normal development and function. Energy restriction inhibits gonadal activity (Mann, 1974; Walker \& Bethea, 1977). The weights of the reproductive organs and their secretions are believed to reflect the availability of testosterone and have been considered as excellent indicators of androgen production (Mann, 1974).

The overall lack of effect of dietary restriction on the characteristics measured in this study suggest that moderate food restriction does not affect testosterone production and the sensitivity of the organs to the hormone. This belief is supported by the results on fertility. The absence of differences in mutagenic index between the groups suggests that sperm quality is not altered by moderate food restriction.

In earlier studies, protein deficiency affected the weights of the male reproductive organs and the concentrations of fructose in the coagulating gland were reduced (Ghafoorunissa, 1975, 1976). Whenever energy or protein is restricted, there is bound to be a concomitant reduction of the other. However, the protein intake of the animals in Group III was not as low as that in animals in the earlier studies in which the diet contained only 7-9\% protein. Similarly, in rats which received the $9 \%$ protein diet, food intake was decreased only by about $20-25 \%$ and so the results of Ghafoorunissa $(1975,1976)$ can be attributed to protein deficiency per se. Considered together, these studies indicate that the reproductive system of the male rat is perhaps more sensitive to protein deficiency than to moderate energy restriction.

Although extrapolations from observations made on experimental animals to man has limitations, they can sometimes be indicative. Demographic studies to obtain similar information in man are not feasible, but the present results suggest that moderate undernutrition, of the order generally seen in adult populations in developing countries, may not be deleterious to the male reproductive system. 
I thank Dr S. G. Srikantia, Director and Dr Kamala S. Jaya Rao, Deputy Director, for their keen interest and valuable suggestions.

\section{References}

Callard, I.P. \& Leathem, J.H. (1970) Pregnancy maintenance in protein deficient rats. Acta endocr., Copenh. 63, 539-544.

Ghafoorunissa (1975) Effect of dietary protein on the biosynthesis of inositol in rat testes. $J$. Reprod. Fert. 42, 233-238.

Ghafoorunissa (1976) Effect of dietary protein and inositol on sperm metabolism and fructose content of male accessory sex organs of rat. Indian J. exp. Biol. 14, 564-566.

Gopalan, C. (1962) Effect of nutrition on pregnancy and lactation. Bull. Wld Hlth Org. 26, 203-211.

Gopalan, C. Naidu, A.N. (1974) Nutrition and fertility. Lancet ii, 1077-1079.

Hoskins, D.D. \& Patterson, D.L. (1968) Metabolism of rhesus monkey spermatozoa. J. Reprod. Fert. 16, $183-195$.

Mann, T. (1964) The Biochemistry of Semen and of the Male Reproductive Tract. Methuen \& Co., London.

Mann, T. (1974) Effects of nutrition on male accessory organs. In Male Accessory Sex Organs, pp. 173181. Ed. D. Brandes. Academic Press, New York.
Morita, Z. \& Chang, M.C. (1970) The motility and aerobic metabolism of spermatozoa in laboratory animals with special reference to the effects of cold shock and the importance of calcium for the motility of hamster spermatozoa. Biol. Reprod. 3, 169-179.

Nelson, M.M. (1959) Relation of dietary protein to reproductive physiology in female rats. In Reproductive Physiology and Protein Nutrition, pp. 2-11. Ed. J. H. Leathem. Rutgers University Press, New Jersey.

Walker, R.F. \& Bethea, C.L. (1977) Gonadal function in underfed rats: effect of pineal gland and constant light on maturity and fecundity. Biol. Reprod. 17, 623-629.

Widdowson, E.M. \& Cowen, J. (1972) The effect of protein deficiency and calorie deficiency on the reproduction of rats. Br.J. Nutr. 27,85-95.

Zubiran, S. \& Gomez-Mont, F. (1953) Endocrine disturbances in chronic malnutrition. Vitams Horm. 11, 97-132.

Received 5 September 1979 